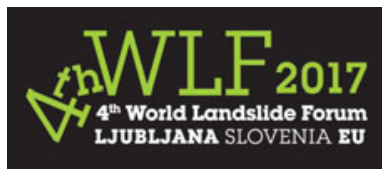

\title{
Mitigation of Landslide Hazards in Ukraine Under the Guidance of ICL: 2009-2016 (IPL-153, IPL-191)
}

\author{
Oleksander Trofymchuk, lurii Kaliukh, Silchenko Konstantin, \\ Viktoriia Berchun, Taras Kaliukh, and laroslav Berchun
}

\begin{abstract}
More than $90 \%$ of the territory of Ukraine has complex soil conditions. The number of landslides has increased by a factor of 1.3 in the last 15 years, and by a factor of about 3 over the last 30 years. Ukraine became a member of ICL only in 2009. The main task of Ukrainian division of ICL (UDICL) from 2009 to 2016 was and still is the implementation of the National Plan (the State Programme) on lanslide hazards mitigation. Because of a lack of governmental or any other support during the above years, UDICL has managed to carry out only two projects and is working on one more on a voluntary base. Objectives of the first IPL project were to determine the slopes with a landslide hazard in the Kharkiv region of Ukraine; to develop a database containing the engineering-geological information relevant to descriptors of landslide sites; and to develop targeted GIS on landslides in the Kharkiv region. All the goals of the project were achieved. In 2012-2014 IPL 153 project was implemented: information about landslide protection structures and measures was collected and structured, prospects of their development in the Autonomous Republic of the Crimea of Ukraine (ARCU) were studied, and the target database was created. Since 2015 "Landslide hazard zonation using GIS", the IPL 191 project, is being realized. The main goal of the project was to develop an instrument for landslide hazard forecasting to minimize the impact of landslide activation on people and tangible objects for the Carpathian region of Ukraine. Two Ukrainian standards of construction objects monitoring and building in the landslide sensitive areas will be completed and put into effect in 20172018. UDICL plans a training programme concerning these building standards for more than 1000 designers from all the regions of Ukraine.
\end{abstract}

\section{Keywords}

Landslide hazards $\bullet$ Experiment $・$ Mitigation $・$ Monitoring $\bullet$ Heritage $・$ Retaining wall

O. Trofymchuk · V. Berchun · I. Berchun

ITIGS NASU, 13 Chokolivsky Blvd., Kiev, 03186, Ukraine

e-mail: itelua@kv.ukrtel.net

V. Berchun

e-mail: berchun2003@yahoo.com

I. Berchun

e-mail: berchun93@gmail.com

I. Kaliukh $(\bowtie) \cdot$ S. Konstantin

Research Institute of Building Constructions, Preobrajenskaya

Str.5/2, Kiev, 03037, Ukraine

e-mail:kalyukh2002@yahoo.com
S. Konstantin

e-mail: kalyukh2002@yahoo.com

T. Kaliukh

Scientific Research Institute of Oil and Gas Industry of National Joint-Stock Company "Naftogaz of Ukraine", Kiev, Ukraine e-mail: tarasklh@gmail.com 


\section{Landslide Work in Ukraine: A Background}

Dr Iurii Kaliukh became aware the ICL after presenting "Theoretical and methodological issues of monitoring of Livadia landslide system and Livadia palace in Crimea, Ukraine" in August 2003 at the National Center of U.S. Geological Survey in Reston (USA). After that he offered to carry out a joint study of landslide hazards in Ukraine, and the Livadia landslide system in particular. He turned to ICL for information. Unfortunately, we became members of ICL only in 2009. From 2003 to 2009 we were trying to find governmental or any other financial support for the ICL entrance fee and further annual fees. However, our attempts had no result. That is why the entrance fee and all further annual fees from 2009 to 2014 were paid at private expense by Dr Olexander Trofymchuk, the director of Institute of Telecommunications and Global Information Space of National Academy of Sciences of Ukraine (NASU). Otherwise Ukraine would not have become a member of ICL

The period from October 2014 to 2016 has been the most difficult for Ukraine since its independence (collapse of the USSR in 1991). There are several reasons: the military aggression of Russian Federation since March 2014, which developed into annexation of the Crimean Peninsula and war in the east of Ukraine (Donbas) a decline in the Ukrainian economy (separation of the Crimea and part of the Donbas, drop in production and investments) a sharp decrease in investments into science and a fall in the living standard of Ukrainian people. In 2015 scientists salaries decreased 3 times in dollar equivalent and Dr Olexander Trofymchuk couldn't pay the annual fee to ICL. In 2016 it was paid from the personal money of Dr Olexander Trofymchuk and Dr Iurii Kaliukh. We are also planning to pay further annual fees together. However, we couldn't participate in many meetings, conferences and congresses of ICL during 20092016 because of lack of governmental or any other type of support. Undoubtedly, it has adversely affected the quality and scientific level of our studies of landslide hazards in Ukraine. Because of the aforementioned reasons, in 20092016 the Ukrainian division of ICL has managed to realize only two projects and now is working on one more project on a voluntary basis.

\section{Introduction}

More than $90 \%$ of the territory of Ukraine has complex soil conditions and about 120,000 sq. km of the Ukrainian territory are located in a seismically active area that has earthquakes with magnitudes varying from 6 to 9 . Therefore, unpredictable changes of natural geological state and man-made factors that determine the ground conditions may cause dangerous deformation processes at heritage sites in Ukraine. This requires the introduction of additional protection measures, such as the creation of monitoring and early warning systems. Landslide processes in Ukraine occupy first place in the ranks of hazard damage. In general, over 23.1 thousand landslides by 01 December 2011 and 17.4 thousand landslides by 01 December 1997 were detected in Ukraine. Thus, the number of landslides has increased by 1.3 times in the last 15 years, and by 3 times over the last 30 years. Massive landslides took place in Kiev in April 2014:

The landslides have been activated again in Kiev. Already 131 land areas are moving in different parts of the city (last year there were 125). Experts say that the large-scale falls of ground can be a threat to the city. The moving land areas can damage the roads, buildings and water, heat and gas pipelines.

Periodic exogenic geological processes activation and complex engineering-geological situations within the South Coast of the Crimea result in landscape transformation and deformation of engineering and architecture structures. Growth in the number of landslides is mainly caused by man-made and combined natural and man-made reasons, and less frequently by natural ones alone.

Man-made reasons have caused about 600 humaninduced landslides in the territory of the South Coast over the recent 100 years that were registered within the South Coast of the Crimea Landslides Cadaster (the total number of landslides in the Crimea by the end of 2009 was 1576). Thus, about $38 \%$ of the South Coast landslides are caused by human activity. The most substantial damage is caused by the landslides threatening the safety of unique architectural, historic and cultural monuments. Over the history of South Coast of the Crimea engineering development, these landslides have caused more damage than earthquakes. At the present moment there is a threatening situation in the vicinity of the Livadia Palace and Park Complex. Intensification of seismic activity in the Vrancea area, the Black Sea region and around the world has led to an increased level of seismic hazard in Ukraine, triggering more landslides. The whole territory of Ukraine (not only just the Carpathian and Crimean regions, as was believed before) is now an area with a high potential risk of future huge earthquakes. The deputy director of the Institute of Geophysics of the NASU, O. Kendzera, says (Newspaper "Segodniya" 2014) "78-magnitude effects can be observed in areas with weakened soils (frequent flooding, landslides, etc.)".

"Before the Japanese earthquake (03.11.2011) it was considered that during a 9-magnitude earthquake acceleration of ground can reach $0.4 \mathrm{~g}$. But the Japanese catastrophe showed as much as $2.7 \mathrm{~g}$. It led to much more damage than it was expected. It means that now we must correct all parameters of earthquakes" noted the director of the 
Armenian Institute of Geophysics and Engineering Seismology S. Ohasyan. A. Kendzera adds: “...We must correct initial data that will be used by designers in building construction". UDICL is working on these challenges.

\section{9-2011}

In 2010-2011 the IPL project "Landslide hazard zonation in Kharkiv region of Ukraine using GIS" was realized. The main goal of the project was to develop an instrument for landslide hazard forecasting to minimize the impact of landslide activation on people and tangible objects, including construction, transportation services, pipelines etc. Its objectives were to determine the slopes subject to landslide hazards slopes over the Kharkiv region of Ukraine; to develop a database containing the engineering-geological information relevant to descriptors (passports) of landslide sites; and to develop targeted GIS on landslides in the Kharkiv region. All goals of the project were achieved. The results of the project were reported at the 2011 WLF2 conference in Rome (Trofymchuk, Kaliukh et al. (2013a, b, c) and published Trofymchuk et al. (2013d) (Fig. 1).

Ph.D. A.S. Glebchuk has defended a dissertation on the topic "Mathematical modeling of landslide's dangers in condition of flooding and seismic influences" (under the supervision of Dr Olexander Trofymchuk) relevant to the IPL project. The dissertation is devoted to system analysis of landslide dangers using mathematical modeling and GIS-technologies for the creation of models that display landslides processes. Landslides slopes were determined in the territory of the Kharkiv region. Databases, including data descriptors of landslide sites and precipitation in the Kharkiv

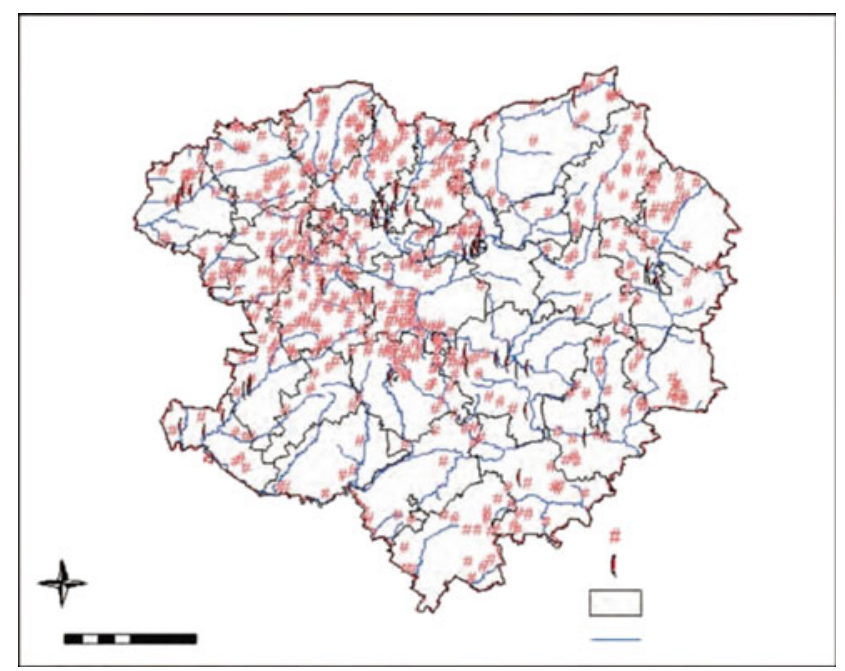

Fig. 1 Map showing the distribution of landslides in the Kharkiv region region, were developed. Developed GIS includes information on relief, steepness of slopes, hydrography, roads and landslide sites of the Kharkov area.

Ukraine has been a member of the "Landslides and Cultural \& Natural Heritage" (LACUNHEN) thematic Network of the ICL (head of the LACUNHEN is Claudio Margottini, Vice President of the International Consortium on Landslides) since 2012. The scope of the LACUNHEN Network has broadened from studying a single heritage site in isolation to a multidimensional, multiregional and inter-disciplinary approach. Within this broader view, landslides, and more generally slope instabilities, are an important factor endangering cultural heritage sites and causing their degradation (Fig. 1). We used an inter-disciplinary approach based on system analysis principles to create the monitoring and early warning system (ZSUV) of the Livadia Palace, placed on the active Central Livadia Landslide system (CLLS), with the aid of the experimental and analytical studies of natural seismic and rainstorm impacts on landslide movement on the deformation of the buildings of the Livadia Palace. The ZSUV system was designed, programmed, and experimentally worked out by multi-day tests using special precision equipment at the National Technical University of Ukraine "KPI" and installed on the CLLS and Livadia Palace, where it operated in real-time mode. Experimental data were obtained on the impact of natural seismic factors and rainstorms on the Central Livadia landslide system and on the Palace itself. And on the basis of this example, the Ukrainian division of ICL represented the TXT-tool "System approach for monitoring of World Heritage sites placed on the active landslides: the monitoring and early warning system of the Livadia Palace building constructions placed on the active CLLS, Ukraine" to ICL.

For a real-time diagnosis of the lithodynamic conditions, an algorithm was developed, and a computer system for monitoring the CLLS was realized, together with real-time maintenance of the data base of lithogenic and other parameters of the CLLS, and manual updating of data using high-level programming language. The real-time program allows monitoring of the level of groundwater and of the deformation angles of landslide bodies; recording of seismic activity, statistical processing of the obtained data, archiving of the obtained data and statistical processing results. The correlation dependence of the seismic activity of CLLS on solar activity is analyzed by maintaining a data base of the solar and lithogenic parameters. In this case the data are entered into the computer manually with the help of the $Z S U V$ because study of these processes does not require any automated system for gathering and accumulation of initial information (the solar cycle of activity increase and decline has a period of 11 years). The solar parameters cover solar activity, changes of temperature and humidity conditions, the character and intensity of fallouts, wind, etc. During the 
Fig. 2 A fragment of the instant information obtained from one of the numerous channels of high-precision sensors in 2002 during monitoring of the structural elements of the Livadia Palace

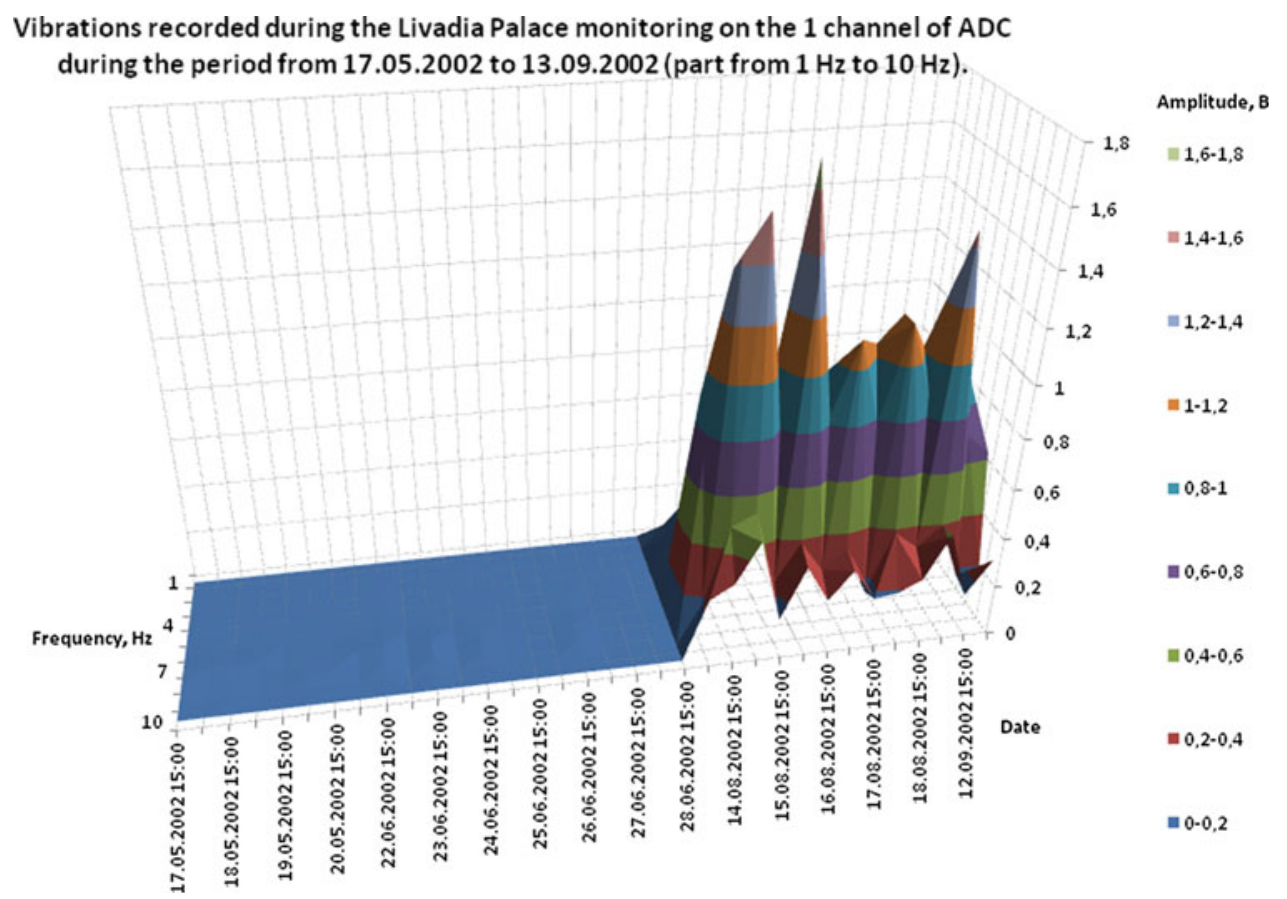

period from mid-December 2001 to December 2002 vibrations of the Livadia Palace (Fig. 2.) caused by seismic activity were measured using high-precision sensors. The spatial position was determined by measuring the inclination angle of the building façade.

\section{2-2014}

In 2012-2014 project IPL 153 "Landslide protection structures and their development in the Autonomous Republic of the Crimea, Ukraine (ARCU)" was realized. Within the framework of IPL Project №. 153 "Landslide protection structures and their development in the ARCU" (term: January 2012-December 2014) information about landslide protection structures and measures was collected and structured, prospects of their development in the ARCU of Ukraine were studied, and the target database was created. Some results of the project were presented in the report "Experimental and analytical studies of landslides in the south of Ukraine under the action of natural seismic impacts at the International Symposium on Earthquake-Induced Landslides, Kiryu, Japan, 2012, other conferences and congresses (Trofymchuk et al. 2013a, b, c), and published in the periodical press (Kaliukh et al. 2014; Kaliukh et al. 2015). Ph.D. K.V. Silchenko has defended a dissertation on "Work of landslide retaining structure that consists of short piles" (under the supervision of Dr Iurii Kaliukh) relevant to the IPL project. The dissertation work is devoted to an experimental and theoretical study of the interaction of short piles with sliding soil; the development and implementation of this type of landslide retaining structure to construction practices in the Crimea, Ukraine. For the first time the experimental distribution diagram of landslide pressure on the frontal surface of short piles with varying lengths was experimentally established. The applied calculation method was developed for short piles on creeping and punching in landslide depth and in an area of short piles installed in stable soils under the action of horizontal loading. Mathematical modeling of stress-strain state for landslide slopes with use of retaining structures as short piles under the action of seismic loads and other factors triggering landsliding (it corresponds to regional features of complex soil conditions in ARCU) were further developed. A typical design section is shown in Fig. 3 of a slope for the case of a maximum difference in heights due to cutting for installation of the object under construction. The stage of a construction pit, when arranging the 2 nd tier of beams for anchor fixing, is shown in Fig. 4.

\section{5-2016}

Since 2015 "Landslide hazard zonation of Carpathian region of Ukraine using GIS" IPL 191 project has been implemented. The main goal of the project was to develop an instrument for landslide hazard forecasting to minimize the impacts of landslide activation on people and tangible objects, including construction, transportation services, pipelines etc. The objective is to determine the slopes prone 
Fig. 3 Typical design section of slope
$1-1$

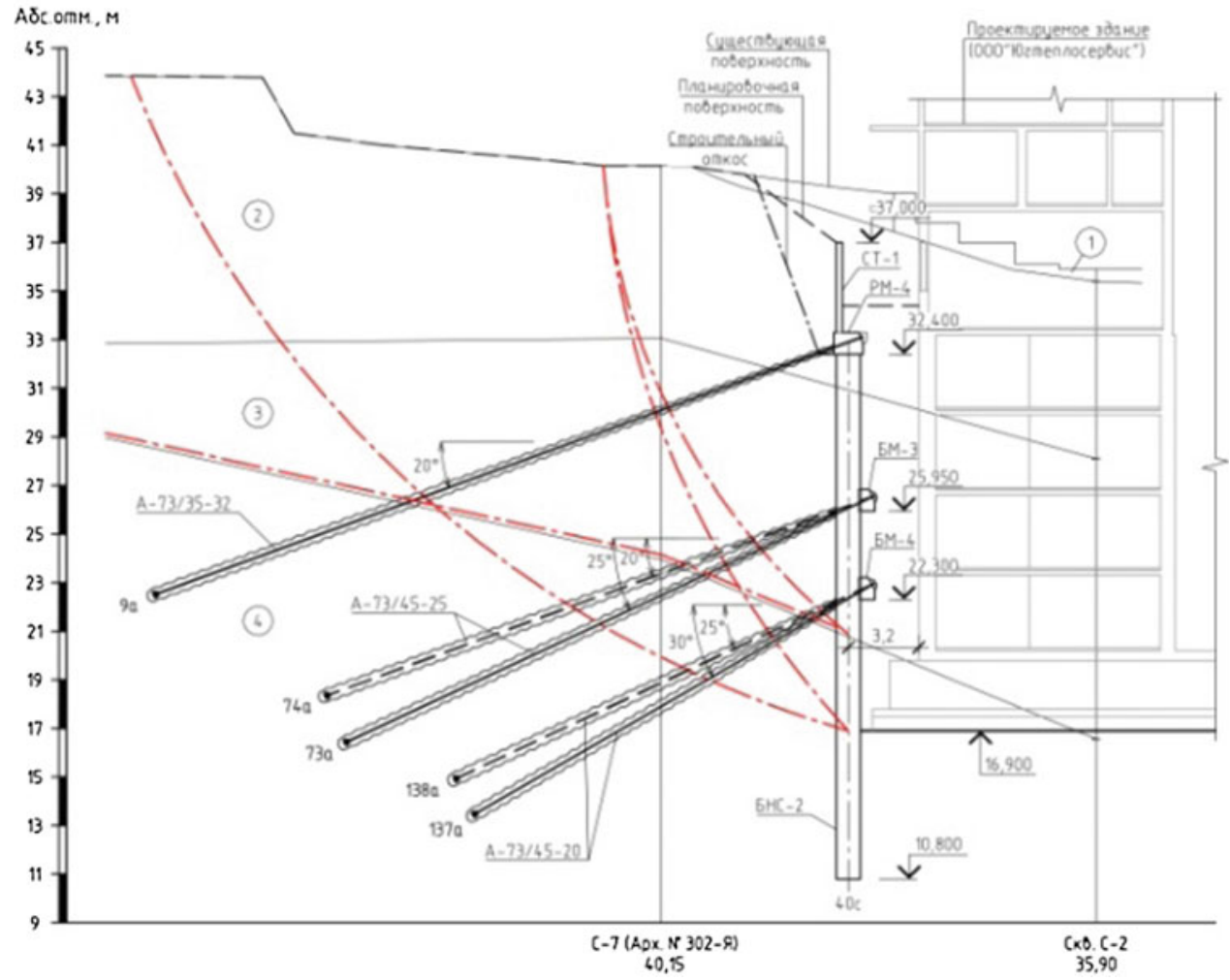

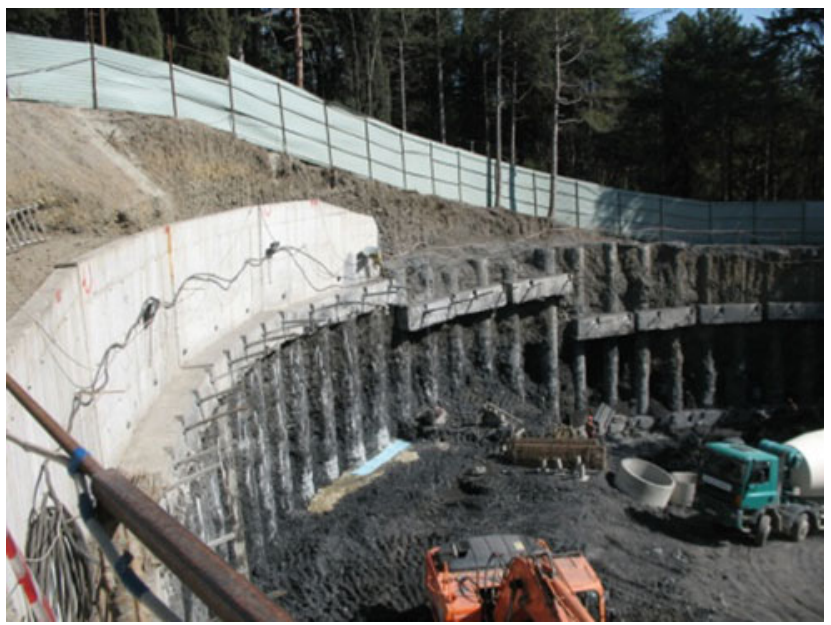

Fig. 4 Stages of construction: pit when arranging the 2nd tier of beams for anchor fixing

to landslide hazards over the Carpathian region of Ukraine; to develop a database containing the engineering-geological information relevant to descriptors of landslide sites; and to develop targeted GIS on landslides in the Carpathian region of Ukraine. Preliminary results of the project were presented in the report "Hazardous Activation of Landslides within Western Carpathian Region (Ukraine)" at the WLF3 conference (Kaliukh et al. 2013a), Trofymchuk et al. (2014b)

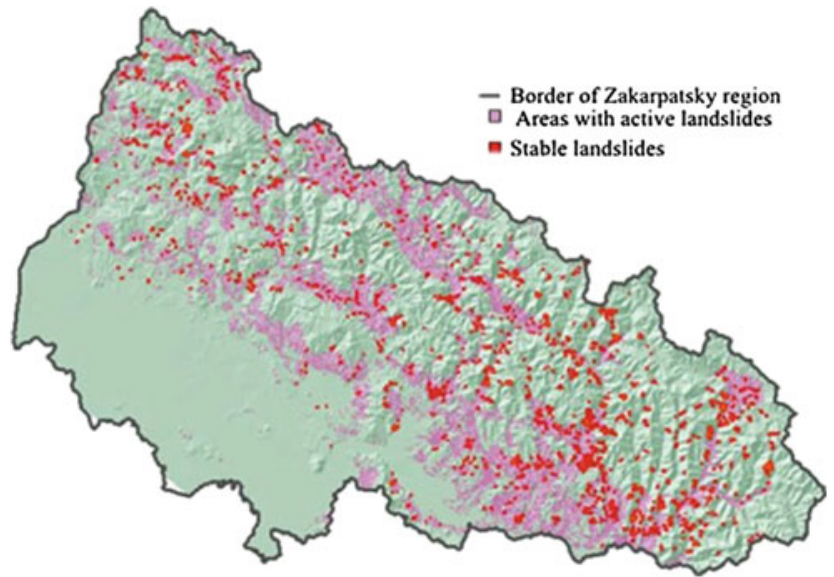

Fig. 5 Remote sensing data on the distribution of landslides sites within the Zakarpatsky region

(Fig. 5) and published in the periodical press (Khavkin and Kaliukh 2014). Ph.D. K.A. Khavkin has defended a dissertation on the topic "Landslide hazard and the stress-strain state of retaining walls in seismic regions of Ukraine (on the example of Bukovina)" (supervisor is Dr Iurii Kaliukh) on the subject of the project.

The dissertation work is devoted to experimental analytical research on the stress state of retaining walls and landslide arrays in the difficult ground conditions of Bukovina 
under dynamic loadings. For the first time the technical and stress state of retaining walls under landslide pressure in Chernovtsy region were investigated using nondestructive methods: integrated vibration diagnostics and ultrasound. Recommendations for repair and reconstruction of retaining walls in the future during a meeting with public servants from the Chernovtsy local municipality are proposed. The elastic and elastic-plastic deformation of ground and variation of its physical and mechanical properties were considered, together with dynamic certification of the current technical state of retaining walls by non-destructive methods (Kaliukh et al. 2016), see Figs. 6 and 7).

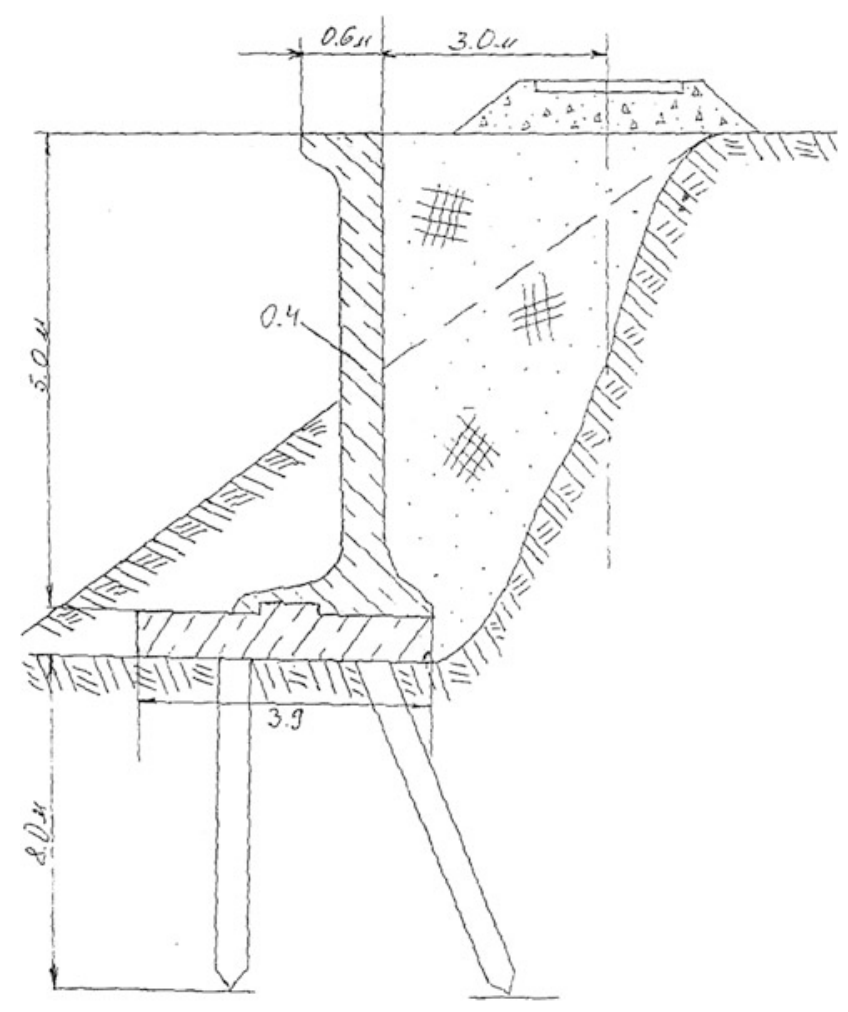

Fig. 6 Scheme of the retaining wall at the railroad haul of Zavalie-Nepolokivtsy

\section{Training and Conferences}

Normative document of the Ministry of Regional Development, Construction, and Communal Living of Ukraine. of Ukraine (Trofymchuk et al. 2013a, b, c) ("Construction in seismic regions of Ukraine: DBN V.1.1-12:2013") was introduced into Ukrainian building practice in 2014. More than 500 designers throughout Ukraine have participated in training programmes according to the new Construction Norms DBN V.1.1-12:2013. The type of accreditation is a certificate.

\section{Capacity Development Programme Concerning DRR and Climate Change}

Seven conferences were held under the supervision of the Institute of Telecommunication and Global Information Space from 2009 to 2015 . One more will be held in October 2016. (Link to 2015: http://itgip.org/14-mizn-nauk-pr-konf/? lang=en [Last accessed: 14 June 2016], Fig. 8).

The journal "Environmental Safety and Natural Resources" is being published by the Institute of Telecommunication and Global Information Space four times per year. Twelve issues that cover problems of DRR and climate change have been published from October, from the beginning of 2000 to October 2016: http://itgip.org/collections_ of_scientific_papers/?lang=en. [Last accessed: 14 June 2016]

\section{Planned Future Activities}

Two Ukrainian standards of construction for scientific and technical monitoring of construction objects and construction for building in the areas sensitive to landslides will be completed and put into effect in Ukrainian building practice in 2017-2018. The Ukrainian division of ICL is planning training programmes in 2017-2020 concerning these issues, based on the new Construction Norms for more than 1000 designers from all the regions of Ukraine. This will allow

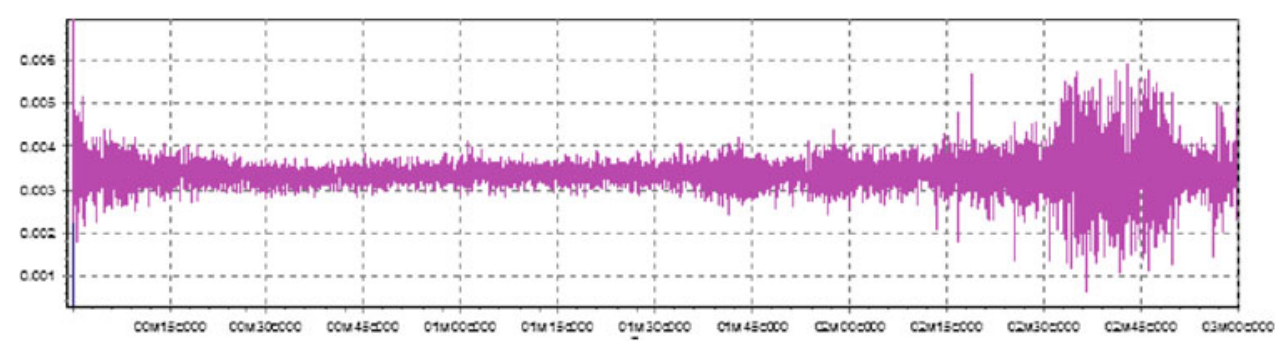

Fig. 7 Graphic of horizontal vibration accelerations of the retaining wall along the $\mathrm{X}$ axis at point 2 at microseismic vibrations and train passage. Vertical axis is signal amplitude; horizontal axis is time (m, c) 


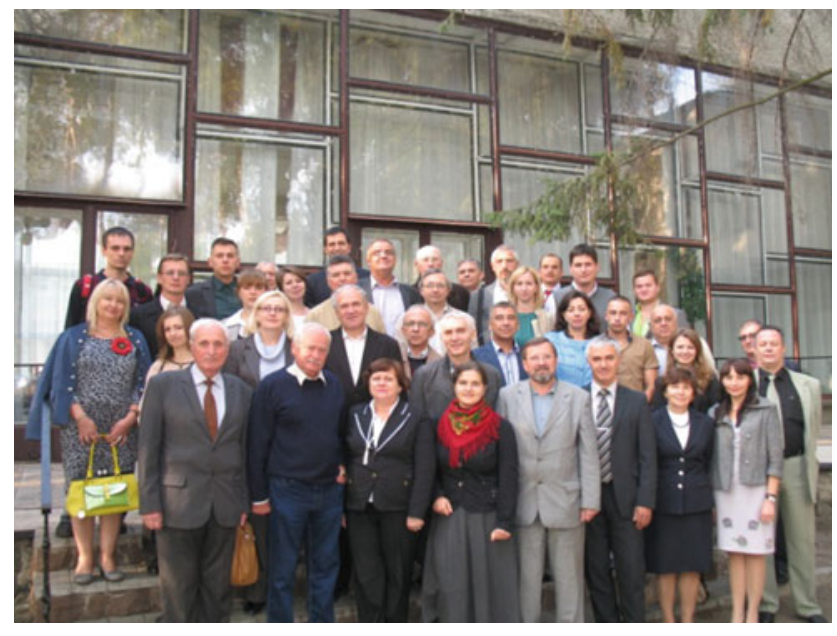

Fig. 8 Participants at the Conference in 2015

them to correct design monitoring systems of construction objects in landslide-prone territory, in particular, to correctly design landslide-protected buildings in areas sensitive to landslides. At the moment Dr Olexander Trofymchuk is the supervisor of Ph.D. student Iaroslav Berchun, whose Ph.D. is devoted to the study of landslide initiation mechanisms in Neogene clay, and Dr Yurii Kaliukh is the supervisor of $\mathrm{Ph}$. D. student Alexander Ischenko, whose Ph.D. is devoted to the study of the stress-deformed state of retaining walls in towns.

As a member of the "Landslides and Cultural \& Natural Heritage" thematic Network of the ICL, we plan the implementation of the new project in 2018-2020. It will be devoted to the study of a single heritage site placed on an active landslide system, in isolation, to one that values a multidimensional, multiregional and inter-disciplinary approach.

\section{Beneficiaries from UDICL}

The main beneficiaries from UDICL are Kharkov (IPL project "Landslide hazard zonation in Kharkiv region of Ukraine using GIS"), the Autonomous Republic of the Crimea, Ukraine (IPL project 153 "Landslide protection structures and their development in the Autonomous Republic of the Crimea, Ukraine") and Chernovtsy (IPL project 191 "Landslide hazard zonation Carpathian region of Ukraine using GIS"); local authorities including Kharkov, ARCU and Chernovtsy Regional State Administration; Kharkov and Chernovtsy City State Administration; Kharkov, ARCU and Chernovtsy District State Administrations. Ministry of Environmental Protection, its Kharkov, ARCU and Chernovtsy Regional Branches; ITGIS of NASU and NDIB; Environmental NGOs and. finally, ICL/IPL-GPC.
Acknowledgements Results presented herein have been obtained with the financial support from private consulting firm "Center of Science-Engineering Service", Yalta, Crimea, Ukraine (owner Michail Rijii). National Academy of Science of Ukraine, the Institute of Telecommunications and Global Information Space has been financing UDICL in years 2009-2016. These supports are much appreciated. We would like to express our appreciation to the Ukrainian scientist from National Technical University "KPI" for consultations during the planning and development of the monitoring systems in the Livadia Landslide System and building constructions of the Livadia Palace. Our special thanks are extended to our colleagues Dr. Iurii Gukovskii, Mr. Ruslan Litvinenko and Dr. Viktor Kochin for their support in the site and office work. We wish to thank numerous citizens and the City of Yalta for their contribution to this project, by enabling use of private and City's land for measurement stations establishment.

\section{References}

Khavkin K, Kaliukh I (2014) Theoretical and applied issues of dynamic certification of the retaining wall in earthquake-prone regions of Ukraine. J Mod Ind Civ Constr 10(1):5-14

Kaliukh I, Senatorov V, et al (2013a) Experimentally-analytical researches of the technical state of reinforce-concrete constructions for defense from landslide's pressure in seismic regions of Ukraine. In: Proceedings of the Fib Symposium. 22-24 Apr 2013, Tel-Aviv, Israel. pp 625-628

Kaliukh I, Trofymchuk O, et al (2013b) Geotechnical problems of diagnosis, monitoring, calculation and engineering protection of hazards landslides and retaining walls in earthquake-prone regions of Ukraine. Experience of the state enterprise state research institute of building structures for the last 5 years. J Svit Geotech 4(40):25-35

Kaliukh I, Silchenko K, et al (2014) Trench strengthening in the restrained conditions of urban development with allowance for the magnitude 8 seismic loads. In: Proceedings of the XV Danube-European Conference on Geotechnical Engineering, 9-11 Sept, Vienna, Austria, pp 535-540

Kaliukh I, Trofymchuk O, et al (2015) Arrangement of deep foundation pit in restricted conditions of city build-up in landslide territory with considering of seismic loads of 8 points. In: Proceedings XVI ECSMGE, 13th-17th Sept 2015, Edinburgh, Great Britain, pp 535-540

Kaliukh I, Farenyuk G, et al (2016) Experimental and theoretical assessment of structural health of existing reinforced concrete retaining walls under low frequency dynamic loading. In: Proceedings of the Fib Symposium, 21-23 Nov 2016, Cape Town, South Africa (in publication)

Newspaper "Segodniya" (2014) Historic Sites are threatened large-scale landslides in Kiev. url:http://kiev.segodnya.ua/ kommunalka/istoricheskim-mestam-kieva-ugrozhayutmasshtabnye-opolzni-512593.html. Last Accessed: 7 Jun 2016

Trofymchuk O, Kaliukh I (2012) The numerical-statistical approach for hazard prediction of landslides and its application in Ukraine. In: Proceedings of the European Geosciences Union General Assembly, poster in session NH3.2. 22-27 Apr 2012. Vienna, Austria. Abstract № EGU 2012-3387

Trofymchuk O, Kaliukh I (2013) Activation of landslides in the south of Ukraine under the action of natural seismic impacts (experimental and analytical studies). J Environ Sci Eng 2(2):68-76

Trofymchuk O, Kaliukh I et al (2013a) Construction in seismic regions of Ukraine: DBN V.1.1-12:2013 (introduced into building practice 2014-10-01). Normative document of the Minregionbud of Ukraine, $118 \mathrm{p}$

Trofymchuk O, Kaliukh I, et al (2013b) Experimental and analytical studies of landslides in the south of Ukraine under the action of 
natural seismic impacts. In: Proceedings of the international symposium on earthquake-induced landslides, Kiryu, Japan. Springer, Berlin, pp 883-890

Trofymchuk O, Kaliukh I, et al (2013c) Mathematical and GIS-modelling of landslides in Kharkov region of Ukraine. In: Proceedings of WLF2. Landslide science and practice. Volume 3. Spatial analysis and modelling. Springer, Berlin, pp 347-352

Trofymchuk O, Kaliukh I, Glebchuc A, et al (2013d) Modelling of landslide hazards in Kharkov Region of Ukraine using GIS. Landslides: global risk preparedness. Springer, Berlin, pp 273-283

Trofymchuk O, Kaliukh I, et al (2014a) Use accelerogram of real earthquakes in the evaluation of the stress-strain state of landslide slopes in seismically active regions of Ukraine. In: Proceedings of the Engineering Geology for Society and Territory-Volume 2. Springer, Berlin, pp 1343-1346

Trofymchuk O, Yakovlev E, et al (2014b) Hazardous activation of landslides within Western Carpathian Region (Ukraine). In: Proceedings of the WLF3. Landslide science for a safer geoenvironment. Volume 2. Methods of landslide studies. Springer, Berlin, pp. 533-536

Trofymchuk O, Kaliukh I, et al (2017) Landslide stabilization in building practice: methodology and case study from Autonomic Republic of Crimea. In: Proceedings of the WLF4. Springer, Berlin (in publication)
Open Access This chapter is licensed under the terms of the Creative Commons Attribution 4.0 International License (http:// creativecommons.org/licenses/by/4.0/), which permits use, sharing, adaptation, distribution and reproduction in any medium or format, as long as you give appropriate credit to the original author(s) and the source, provide a link to the Creative Commons license and indicate if changes were made.
The images or other third party material in this chapter are included in the chapter's Creative Commons license, unless indicated otherwise in a credit line to the material. If material is not included in the chapter's Creative Commons license and your intended use is not permitted by statutory regulation or exceeds the permitted use, you will need to obtain permission directly from the copyright holder. 